\title{
Konsekuensi Yuridis Perubahan Obyek Hak Tanggungan dalam Akad Pembiayaan Mudharabah
}

\author{
Septi Kurniawati \\ Magister Kenotariatan Fakultas Hukum Universitas Islam Indonesia \\ Jln. Cik Di Tiro No. 1, Yogyakarta, 55223 \\ septikenandito@gmail.com
}

\begin{abstract}
Mudharabah is a partnership contract in business sector where the results will be divided in half. Mudharabah does not use collateral, guarantees are requested if the mudharib (debtor) is feared to be incapable to fulfill its performance. If mudharib fails to pay, then the execution can be carried out as compensation which is the right of Shobibul Maal (creditor). In this paper there are two problems: what must be done to change an object on the mortgage right and the consequences; and what if it is linked using a mudharabah agreement. This research is normative, in which the data is obtained from laws, literature, electronic media and through analysis of the Supreme Court's Decision which is then analyzed as a whole qualitatively. Decision of the Supreme Court No. 410K/Ag/2014 states that the Deed that has been signed and agreed with the conscious has absolute legal force that cannot be canceled for any reason. The change of an object in the Underwriting Right with a Mudharabah agreement has consequences for permanent or binding legal force on the parties. This was proven in the Supreme Court Decree No. 410K/Ag/2014 that the change of object in the Mortgage Rights with the Mudharabah agreement was justified by the Judge.
\end{abstract}

Keywords: Mudharabah contract; borgtocht; underwriting rights

\begin{abstract}
Abstrak
Mudharabah merupakan akad kerjasama di bidang usaha yang mana hasil akan dibagi dua. Mudharabah tidak menggunakan jaminan, jaminan dimintakan apabila mudharib (debitur) dikhawatirkan tidak dapat memenuhi prestasinya. Jika mudharib mengalami gagal bayar, maka eksekusi dapat dilaksanakan sebagai ganti rugi yang merupakan hak dari shobibul maal (kreditur). Dalam tulisan ini terdapat dua permasalahan: hal apa saja yang harus dilakukan ketika akan melakukan perubahan obyek pada hak tanggungan berikut konsekuensinya; dan bagaimana jika dikaitkan menggunakan akad mudharabah. Penelitian ini bersifat normatif, yang mana data di dapat dari Undang-Undang, literatur, media elektronik serta melalui analisis Putusan Mahkamah Agung yang kemudian secara keseluruhan dianalisis secara kualitatif. Putusan Mahkamah Agung Nomor 410K/Ag/2014 menyatakan bahwa Akta yang telah ditandatangani dan disetujui dengan sadar mempunyai kekuatan hukum mutlak yang tidak dapat dibatalkan dengan alasan apa pun. Perubahan obyek pada Hak Tanggungan dengan akad Mudharabah memiliki konsekuensi kekuatan hukum tetap atau mengikat pada para pihaknya. Hal ini dibuktikan pada Putusan Mahkamah Agung Nomor 410K/Ag/2014 bahwa perubahan obyek pada Hak Tanggungan dengan akad Mudharabah dibenarkan oleh Hakim.
\end{abstract}

Kata-kata Kunci: Akad Mudharabah; borgtocht; hak tanggungan 


\section{Pendahuluan}

Kehidupan manusia tidak terlepas dari perbuatan hukum yang di antaranya adalah transaksi utang piutang. Kegiatan utang-piutang dapat dilakukan antara orang perorangan dengan badan hukum atau sebaliknya. Lembaga keuangan baik bank ataupun non-bank dengan terang memberikan suatu fungsinya sebagai pemberi pinjaman. Pinjam meminjam diperlukan agunan atau jaminan baik berupa benda bergerak maupun benda yang tidak bergerak. Kebendaan orang yang berhutang baik yang bergerak maupun tidak bergerak, baik yang sudah ada maupun yang akan ada dikemudian hari menjadi tanggungan untuk segala perikatan perorangan. ${ }^{1}$ Fungsi jaminan adalah untuk memberi rasa aman terhadap kreditur dan dapat digunakan sebagai pelunas hutang apabila debitur tidak dapat melunasinya. Lembaga hak jaminan yang kuat dan mampu memberikan kepastian hukum bagi pihak-pihak yang berkepentingan sangat diperlukan.

Salah satunya, Undang-Undang Republik Indonesia Nomor 4 Tahun 1996 tentang Hak Tanggungan Atas Tanah Beserta Benda-Benda yang Berkaitan dengan Tanah (UUHT) lahir untuk mengatur mengenai beberapa aspek dari perihal tersebut. UUHT mulai berlaku dan menghapus ketentuan tentang hipotek dan Creditverband. Pada awalnya UUHT mengatur benda yang dapat dijaminkan dengan jaminan hipotek adalah hak-hak tertentu atas tanah, seperti Hak Guna Usaha (HGU), Hak Milik (HM), Hak Guna Bangunan (HGB) dan Hak Pakai, belum dapat digunakan sebagai jaminan hutang. Namun seiring berjalannya waktu, UUHT kemudian berlaku, sehingga Hak Pakai tertentu wajib didaftarkan dan menurut sifatnya dapat dipindahtangankan dan dapat dijadikan sebagai objek hak tanggungan. Selain itu, dalam rangka proses pembangunan di bidang ekonomi pada umumnya dan real estate pada khususnya, benda seperti Rumah Susun, Apartemen dan Kondominium diberi kesempatan untuk dijadikan sebagai obyek hak tanggungan. ${ }^{2}$

${ }^{1}$ R. Subekti \& R Tjitrosudibio, Kitab Undang-Undang Hukum Pertdata, Cetakan Ketiga Puluh Sembilan Pradnya Paramita, Jakarta, 2008, hlm. 336.

2 Agus Yudha Hernoko, "Hukum Perdata 'Hukum Orang \& Keluarga", Bahan Kuliab Fakultas Hukum Universitas Islam Indonesia, Yogyakarta, 2017, hlm. 23. 
Obyek hak tanggungan dapat dibebani lebih dari satu hak tanggungan guna menjamin pelunasan lebih dari satu hutang, atas hal tersebut terdapat pemegang hak tanggungan peringkat pertama, peringkat kedua dan seterusnya. Peringkat hutang ditentukan menurut tanggal pendaftarannya di kantor pertanahan atau nomor akta pemberiannya, pembuatan beberapa akta pemberian hak tanggungan atas obyek yang sama hanya dapat dilakukan oleh PPAT yang sama. Obyek hak tanggungan tetap mengikuti meskipun berpindahtangan dari pemberi hak tanggungan kepada pihak lain. Kreditur pemegang hak tanggungan masih tetap dapat menggunakan haknya melakukan eksekusi jika debitur cedera janji. Obyek jaminan dapat diganti dengan melepaskan obyek pada hak tanggungan. Dilepasnya hak tanggungan tidak berarti bahwa hutang menjadi lunas atau berkurang.

Maka dari itu, penelitian ini dilakukan untuk membahas perihal mengenai obyek hak tanggungan dalam akad mudharabah, dengan bercermin pada Kasus perdata dengan pokok perkara perubahan obyek hak tanggungan yang telah diputus oleh Mahkamah Agung tersebut adalah Putusan Nomor 410K/Ag/2014.

\section{Rumusan Masalah}

Dalam tulisan ini akan dipaparkan dua pokok permasalahan, pertama, hal apa sajakah yang harus dilakukan ketika akan melakukan perubahan obyek pada hak tanggungan beserta konsekuensinya? Kedua, bagaimanakah jika dikaitkan menggunakan akad mudharabah?

\section{Tujuan Penelitian}

Tujuan dari penelitian ini adalah untuk mengetahui dan menganalisis perubahan obyek pada hak tanggungan konsekuensi kekuatan hukumnya; dan sifat obyek hak tanggungan yang dikaitkan dengan akad mudharabah.

\section{Metode Penelitian}

Sesuai dengan judul penelitian ini maka sebagai obyek penelitian yaitu putusan Mahkamah Agung yang berkaitan dengan akad pembiayaan mudharabah 
menggunakan jaminan yang disertai dengan perubahan obyek pada hak tanggungan.

Berdasarkan judul penelitian dan rumusan masalah serta latar belakang masalah di atas, maka jenis penelitian ini adalah penelitan hukum normatif yaitu penelitian hukum yang dilakukan dengan meneliti bahan pustaka atau sumber data sekunder belaka. ${ }^{3}$ Penelitian hukum normatif mencakup penelitian putusan Mahkamah Agung yang berkaitan dengan akad pembiayaan mudharabah menggunakan jaminan yang disertai dengan perubahan obyek pada hak tanggungan. Dilampirkan juga mengenai peraturan-peraturan mengenai hak tanggungan dan mengenai pembiayaan akad mudharabah.

Penulisan ini adalah penelitian normatif karena itu pendekatan yang digunakan adalah pendekatan yuridis atau metode yang dalam proses pendekatannya meninjau dan mengkaji objek penelitian dari aspek yuridis yang terkait dengan objek penelitian tersebut yaitu putusan Pengadilan Negeri yang memutus sengketa yang berkaitan dengan akad pembiayaan mudharabah menggunakan jaminan yang disertai dengan perubahan obyek pada hak tanggungan.

\section{Hasil Penelitian dan Pembahasan}

Putusan Mahkamah Agung yang mengacu pada pertimbangan Putusan Pengadilan Tinggi Agama Yogyakarta tampaknya telah menjawab rumusan masalah yang pertama pada tulisan ini. Kasus perdata dengan pokok perkara perubahan obyek hak tanggungan yang telah diputus oleh Mahkamah Agung tersebut adalah Putusan Nomor 410K/Ag/2014, dengan penggugat Budi Legowo dan Akhadina Nurhayati Agustien dan dengan tergugat PT. Bank Tabungan Negara (Persero) Tbk Kantor Cabang Syariah. Berdasarkan putusan tersebut telah memuat fakta bahwa pada tanggal 30 Juli 2008, Penggugat I yaitu Budi Legowo telah mengikatkan diri kepada Tergugat II yaitu Pusat Koperasi Syariah Yogyakarta BMT Amratani. Perjanjian dilakukan dengan akad kerja sama melalui peminjaman sertifikat tanah milik penggugat II yaitu Akhadina Nurhayati

3 Soerjono Soekanto \& Sri Mamudji, Penelitian Hukum Normatif: Suatu Tinjauan Singkat, Rajawali Pers, Jakarta, 2014. 
Agustien. Perjanjian yang dilakukan menimbulkan hak dan kewajiban yang harus dipenuhi kedua belah pihak, yaitu pihak Koperasi Amratani karena telah menerima sertifikat dari Budi Legowo, maka ia berkewajiban untuk menyerahkan sejumlah uang setiap bulannya kepada pihak Budi Legowo sebesar Rp 1.616.800,00 (satu juta enam ratus enam belas ribu delapan rupiah). Pada bulan April 2010, pihak Koperasi Amratani tidak dapat lagi melakukan kewajibannya untuk membayar uang setiap bulan. Koperasi Amratani memutuskan untuk melakukan pinjaman ke pihak Bank BTN Syariah dengan menggunakan akad Mudharabah sejumlah Rp. 1.500.000.000,00 dengan menggunakan beberapa sertifikat secara kolektif sebagai jaminannya. Sertifikat yang digunakan salah satunya yaitu atas nama Dr. Kuswandi. Pihak bank kemudian memasang Hak Tanggungan pada sertifikat-sertifikat yang di jaminan, dalam waktu yang bersamaan pihak Koperasi Amratani mengganti sertifikat milik Dr. Kuswani dengan sertifikat Budi Legowo dengan atas nama Akhadina Nurhayati Agustien.

Penggantian sertifikat tersebut dilakukan dengan tujuan agar pihak Budi Legowo juga akan menerima uang pinjaman dari Bank BTN, atas dasar hal tersebut maka pihak Budi Legowo menyetujuinya dan menandatanganinya. Beberapa bulan kemudian Koperasi Amratani tidak juga memberi uang kepada Budi Legowo, di sisi lain pihak Koperasi Amratani juga tidak dapat melakukan pembayaran pada Bank BTN, sehingga pada tanggal 20 September 2010, pihak bank melelang rumah dari pihak Budi Legowo dengan Nomor 741/BTN/KCSYk/IX/2010. Setelah diumumkan pelelangan belum juga ada pihak yang tertarik untuk menawarnya. Karena rumah atas nama sertifikat milik Budi Legowo telah dilelang maka atas dasar hal tersebut pihak Budi Legowo mengajukan gugatan perdata ke Pengadilan Negeri Sleman karena merasa telah dirugikan. Budi Legowo meminta ke pengadilan agar Pihak bank dengan sukarela membebaskan sertifikat miliknya tanpa syarat apa pun yang berada di bawah kekuasaan Bank BTN. Perkara perdata tersebut didaftarkan pada tanggal 28 Januari 2011 dan diputus pada tanggal 16 Agustus 2011. Perkara tersebut diputus dengan Nomor 07/Pdt.6/2011/PN.Slmn yang memutuskan bahwa gugatan tersebut ditolak seutuhnya. Pada 28 Maret 2012, pihak Budi Legowo mengajukan 
somasi melalui Pengadilan agama Bantul kepada pihak bank agar dapat menyerahkan sertifikat miliknya dengan sukarela. Gugatan diajukan melalui Pengadilan Agama karena atas perjanjian hak tanggungan Nomor 114/2008 Pasal 4 menyatakan bahwa apabila terjadi sengketa, maka para pihak memilih untuk menyelesaikan pada kantor Kepaniteraan Agama di Bantul.

Bertepatan pada tanggal 26 November 2012 Pengadilan Agama Bantul telah menjatuhkan putusan Nomor 0328/Pdt.G/2012/PA.Btl dan Pengadilan Tinggi Agama Yogyakarta membatalkan putusan Pengadilan Agama Bantul dengan putusan Nomor 05/Pdt.G/2013/ PTA.Yk.atas dasar dalam perkara tersebut tidak terdapat kekhilafan dan atau kekeliruan yang nyata dalam menerapkan hukum dan Peraturan Perundang-Undangan yang berlaku. Pada putusan Nomor 410K/Ag/2014 Mahkamah Agung memutus bahwa gugatan kasasi ditolak dan putusan ini merupakan putusan yang terakhir dan tidak ada upaya hukum lagi.

Perjanjian pada pemasangan hak tanggungan obyeknya dapat diubah dan tidak berpengaruh pada perjanjian pokoknya. Putusan Mahkamah Agung memutus bahwa akta yang telah ditandatangani dan disetujui dengan sadar mempunyai kekuatan hukum mutlak dan tidak dapat dibatalkan dengan alasan apa pun. Obyek hak tanggungan sebagai perjanjian tambahan bersifat accessoir. Ketentuan perubahan hak tanggungan diatur pada Pasal 1 sampai dengan Pasal 17 Undang undang Hak Tanggungan Nomor 4 Tahun 1996. Perubahan obyek pada hak tanggungan dapat dilakukan dengan cara peralihan. ${ }^{4}$ Peralihan Hak Tanggungan dapat dilakukan dengan beberapa cara, yaitu:

\section{Cessie}

Penyerahan hak-hak piutang atas nama, khususnya untuk benda bergerak dilakukan dengan cessie. Cessie merupakan penggantian orang berpiutang damai (disebut: cedent), dengan seseorang berpiutang baru (Cessionaris). Misalnya, A berpiutang pada B, tetapi A menyerahkan piutang itu kepada $C$, sehingga $C$ lah yang berhak atas piutang yang ada pada B. Menurut Pasal 613KUHPerdata, penyerahan itu harus dilakukan dengan akta autentik atau bawah tangan.

${ }^{4}$ Undang-Undang No. 4 Tahun 1996 tentang Hak Tanggungan Atas Tanah Beserta Benda-Benda yang Berkaitan dengan Tanah, Pasal 18 ayat (1) huruf b. 
Penyerahan secara lisan tidak sah. Ada dua persyaratan yang harus dipenuhi supaya Cessie itu mempunyai kekuatan atau daya berlaku terhadap debitur, yaitu:

a. Pemberitahuan penyerahan secara nyata dari cedent (piutang lama) kepada debitur

b. Adanya pengakuan dari debitur secara tertulis, apabila pemberitahuan itu tidak dilakukan, debitur dapat melakukan pembayaran terhadap cedent, asalkan debitur masih menganggap cedent sebagai kreditur yang jujur

\section{Subrogasi}

Penggantian kreditur oleh pihak ketiga yang melunasi utang debitur. Terdapat 2 cara terjadinya subrogas, yaitu karena : Perjanjian (kontraktual) dan Undang-undang. Supaya subrogasi ini dianggap sah, maka harus diikuti dengan tata cara sebagai berikut:

a. Pinjaman uang harus ditetapkan dengan akta

b. Dalam akta autentik harus dijelaskan besarnya jumlah pinjaman dan diperuntukkan melunasi utang debitur

c. Tanda pelunasan, berisi pernyataan bahwa uang utang yang diserahkan pada kreditur yaitu uang yang berasal dari pihak ketiga.

Akibat adanya subrogasi yaitu beralihnya hak tuntutan dari kreditur pada pihak ketiga. Peralihan hak itu meliputi hak dan tuntutan, seperti yang tertuang dalam Pasal 140 KUHPerdata).

a) Pewarisan: yaitu pengalihan hak tanggungan pada ahli warisnya sesuai dengan ketentuan di dalam hukum waris yang dianut pemegang hak tanggungan

b) Sebab-sebab lain, yaitu hal-hal lain selain yang telah disebutkan di dalam UU Hak Tanggungan. Contohnya di dalam hal terjadinya pengambilalihan atau penggabungan perusahaan, sehingga menyebabkan beralihnya piutang dari perusahaan semula kepada perusahaan baru.

Dilepaskannya hak tanggungan oleh debitur harus dilakukan dengan pemberian pernyataan tertulis yaitu dengan akta yang dikeluarkan oleh Notaris atau PPAT. Isi dari akta peralihan hak tanggungan menyesuaikan dengan perikatan yang terjadi di antara para pihak. Peralihan obyek hak tanggungan harus didaftarkan ke badan pertanahan, hal tersebut untuk mempermudah kepala kantor pertanahan 
mengetahui bahwa benar telah terjadi peralihan piutang yang menyerahkan suatu pernyataan tertulis dari debitur pemegang hak tanggungan yang lama ke pemegang yang baru. ${ }^{5}$ Berbeda dengan peralihan obyek hak tanggungan, hapusnya perikatan sebagai perjanjian pokok dapat dilakukan dengan cara: 6

1) Karena pembayaran;

2) Karena penawaran pembayaran tunai, diikuti dengan penyimpanan atau penitipan;

3) Karena pembaharuan utang;

4) Karena perjumpaan utang;

5) Karena perjumpaan utang dan kompensasi;

6) Karena percampuran utang;

7) Karena pembebasan utang;

8) Karena musnahnya barang yang terutang;

9) Karena kebatalan atau pembatalan;

10) Karena berlakunya suatu syarat batal;

11) Karena lewatnya waktu.

Peralihan obyek hak tanggungan cukup dibuktikan dengan akta mengenai perbuatan hukum yang mengakibatkan beralihnya piutang yang dijaminkan kepada debitur baru. Kewajiban untuk mendaftarkan obyek hak tanggungan yang telah dialihkan akan dibubuhkan catatan pada buku tanah obyek yang dibebani oleh kantor pertanahan sejak tanggal pendaftaran. Catatan tersebut kemudian akan disalin pada sertifikat hak tanggungan dan sertifikat objeknya. Tanggal pencatatan pada buku tanah adalah tanggal ketujuh setelah diterimanya secara lengkap suratsurat yang diperlukan bagi pendaftaran beralihnya hak tanggungan dan jika hari ketujuh itu jatuh pada hari libur, catatan itu diberi tanggal hari kerja berikutnya. Beralihnya Hak Tanggungan mulai berlaku bagi pihak ketiga pada hari tanggal pencatatan tersebut. Hak tanggungan tetap mengikuti obyeknya, meskipun sudah berpindahtangan dari pemberi hak tanggungan kepada pihak lain. Artinya kreditur pemegang hak tanggungan masih tetap dapat menggunakan haknya melakukan eksekusi jika debitur cedera janji.

Peralihan hak atas tanah yang terjadi di Indonesia Para Kepala Kantor Pertanahan Kabupaten atau Kota Madya di seluruh Indonesia harus menyelesaikan

5 Boedi Harsono, Hukum Agraria Indonesia: Sejarah Pembentukan Undang-Undang Pokok Agraria, Isi dan Pelaksanaannya, Djambatan, Jakarta, 2008, hlm. 450.

${ }^{6}$ Kitab Undang-Undang Hukum Perdata, Pasal 1381. 
setiap permohonan atas pendaftaran peralihan hak atas tanah yang sudah bersertifikat atau sudah dilengkapi dengan dokumen-dokumen sebagaimana dipersyaratkan dalam waktu 2 minggu setelah tanggal penerimaan permohonan tersebut. Semua tunggakan permohonan peralihan hak atas tanah yang sudah bersertifikat harus diselesaikan dan sudah dilengkapi dengan dokumen-dokumen yang dipersyaratkan dalam watu 3 (tiga) bulan setelah tanggal instruksi ini.

Pada putusan Mahkamah Agung Nomor 410/Ag/2014 yang diputus pada Senin tanggal 29 September 2014 oleh Prof. Dr. H. Abdul Manan, S.H., S.IP., M.Hum, Hakim Agung yang ditetapkan oleh Ketua Mahkamah Agung sebagai Ketua Majelis, Dr. H. Mukhtar Zamzami, S.H., M.H. dan Dr. H. Habiburrahman, M.Hum, Hakim-Hakim Agung sebagai Anggota dan diucapkan dalam sidang terbuka untuk umum pada hari itu juga oleh Ketua Majelis beserta Hakim-Hakim Anggota tersebut dan dibantu oleh Drs. H. Yayan Atmaja, S.H., M.H., Panitera Pengganti, dengan tidak dihadiri oleh para pihak. Memperhatikan pasal-pasal dari Undang-Undang Nomor 48 Tahun 2009 tentang Kekuasaan Kehakiman, UndangUndang Nomor 14 Tahun 1985 tentang Mahkamah Agung sebagaimana telah diubah dengan Undang-Undang Nomor 5 Tahun 2004 dan perubahan kedua dengan Undang-Undang Nomor 3 Tahun 2009, Undang-Undang Nomor 7 Tahun 1989 tentang Peradilan Agama sebagaimana telah diubah dengan Undang-Undang Nomor 3 Tahun 2006 dan perubahan kedua dengan Undang-Undang Nomor 50 Tahun 2009 serta peraturan perundang-undangan lain yang bersangkutan, mengadili dengan menolak permohonan kasasi dari para pemohon kasasi .

Pembatalan akta yang diajukan pada Mahkamah Agung yang memutuskan untuk menolak permohonan penggugat untuk membatalkan akta yang sebelumnya telah ditandatangani dan disetujui dengan sadar. Penggugat mengajukan gugatan pembatalan akta karena penggugat merasa telah dirugikan terhadap perjanjian tersebut. Penggugat atau pemohon kasasi diketahui secara hukum telah setuju untuk menjaminkan tanahnya yang berupa SHM Nomor 05074 di Ngestiharjo yang ditandai dengan adanya surat adendum yang dibubuhi tambahan tanda tangan dari para penggugat/para pemohon kasasi yang menjelaskan bahwa perbuatan hukum tersebut telah memiliki kepastian hukum. Pada keadaan yang sadar pihak penggugat 
turut menyetujui perbuatan hukum bahwa sertifikat yang ia miliki dijadikan sertifikat jaminan pengganti milik Prof. Dr. Kuswandi dengan SHM Nomor 658/Maguwoharjo. Menurut keterangannya penggugat melakukan hal tersebut karena pihak tergugat mengancam apabila penggugat tidak mengikutinya maka uangnya tidak akan dikembalikan sesuai perjanjian di awal. Penggugat berkeyakinan bahwa perjanjian tersebut bertentangan dengan syariat Islam karena mengandung tipu muslihat, ancaman dan pura-pura. Pasalnya setelah penggugat menandatangani perubahan pada obyek hak tanggungan tersebut ia tidak kunjung mendapatkan uang seperti yang telah dijanjikan oleh tergugat.

Pengadilan tidak boleh menolak untuk memeriksa, mengadili, dan memutus suatu perkara, melainkan wajib untuk memeriksa dan mengadilinya. Perkara yang tidak ada aturannya di dalam hukum atau belum pernah diputus, hakim berkewajiban untuk melakukan penemuan hukum (rechtsvinving) sehingga hakim tidak hanya sekedar menerapkan hukum.7 Mahkamah Agung pada putusan kasasi perkara perdata ini meneliti dengan saksama memori kasasi dan kontra memori, dihubungkan dengan pertimbangan judex facti in casu dan menyatakan bahwa menurut Mahkamah Agung, Pengadilan Agama Yogyakarta yang membatalkan putusan Pengadilan Agama Bantul ternyata tidak salah menerapkan hukum dan peraturan perundang-undangan yang berlaku.

Mahkamah Agung menyatakan bahwa suatu perjanjian yang telah disetujui dengan sadar merupakan suatu peristiwa yang sah dimata hukum. Sehingga gugatan untuk pembatalan suatu akta ditolak oleh Mahkamah Agung. Dalam hal ini berlaku kaidah hukum imperatif yang bersifat apriori harus ditaati, bersifat mengikat dan memaksa ${ }^{8}$. Seseorang yang telah melakukan perbuatan hukum maka ia harus menaati kaidah-kaidah hukum yang telah mengatur perbuatan tersebut.

Keputusan yang diambil oleh hakim merupakan reaksi terhadap suatu sengketa yang faktanya telah dipelajari dan diyakini oleh hakim. Keputusan suatu sengketa yang telah diputus dan dituangkan di dalam putusan artinya mempunyai kekuatan hukum tetap. Hakim merumuskan peraturan-peraturan yang berlaku umum bagi setiap orang yang bersengketa dan memberikan keadilan yang sama

\footnotetext{
7 Undang-Undang No. 4 Tahun 2004 tentang Kekuasaan Kehakiman, Pasal 16 ayat (1).

8 Sudikno Mertokusumo, Mengenal Hukum, Universitas Atma Jaya Press, Yogyakarta, 2010, hlm. 46.
} 
di mata hukum (equality before the law)9. Kaidah hukum bukan selalu dalam bentuk tertulis maupun tidak, tetapi dapat juga berupa perilaku atau peristiwa dan di dalam perilaku itulah terdapat hukumnya yang harus digali serta ditemukan.

Hakim menolak gugatan Budi Legowo pada pengadilan agar membebaskan sertifikat yang berada di bawah kekuasaan Bank BTN. Putusan Mahkamah Agung memutus bahwa akta yang telah ditandatangani dan disetujui dengan sadar mempunyai kekuatan hukum mutlak dan tidak dapat dibatalkan dengan alasan apa pun. Hakim berpendapat bahwa pihak yang telah menandatangani dan menyetujui suatu perjanjian dengan sadar seharusnya sudah mengetahui akan resiko dan akibat hukum yang akan terjadi apabila dikemudian hari terjadi masalah atau kemacetan yang dilakukan. Pembatalan perjanjian juga dapat dilakukan berdasarkan kekhilafan atau sering yang disebut dwaling, hal tersebut adalah :

1. Kekhilafan yang terjadi mengenai hakikat barang atau obyek hukum yang dijadikan sebagai pokok perjanjian namun tidak sesuai apa yang telah diperjanjikan. Hakekat barang yang dimaksud adalah keadaan dari barang yang menjadi dasar dibuatnya perikatan oleh para pihak.

2. Kekhilafan yang terjadi mengenai dari diri pihak lawannya atau subyek hukum, dalam perjanjian yang dibuat terutama mengingat dirinya.

Telah disebutkan bahwa tiada kata sepakat yang sah apabila sepakat itu diberikan karena kekhilafan, atau diperolehnya dengan paksaan atau penipuan. ${ }^{10}$ Kekhilafan tersebut dapat dimintakan pembatalan perjanjian, selain itu untuk menilai tindakan yang merupakan suatu kekhilafan yaitu dapat berupa :

1. Kekhilafan yang terjadi karena motif. Motif merupakan faktor pertama yang menimbulkan suatu kehendak. Hukum pada asasnya memperhatikan motif dari seseorang atau para pihak.

2. Kekhilafan semu, apabila kehendak dan pernyataan yang terjadi tidaklah sama

3. Kesesatan yang sebenarnya, terjadi apabila kehendak dan pernyataan adalah kehendak yang sama.

Dari ketentuan-ketentuan tersebut, dapat dikatakan bahwa dengan dari adanya kekhilafan mengakibatkan dapat dibatalkannya suatu perjanjian. Atau

\footnotetext{
${ }^{9}$ Ibid, hlm. 42.

${ }^{10}$ Kitab Undang-Undang Hukum Perdata, Pasal 1321.
} 
dengan kata lain, selama belum dibatalkannya perjanjian tersebut, maka perjanjian tersebut tetap berlaku dan mengikat kedua belah pihak. Undang undang menyebutkan syarat sahnya suatu perjanjian yaitu kata sepakat oleh para pihak yang telah mengikatkan diri, pihak yang membuat perjanjian haruslah cakap, suatu hal tertentu dan sebab yang halal11. Syarat pertama dan syarat kedua merupakan sebagai syarat subjektif karena mengenai subyeknya yang mengadakan perjanjian dan jika syarat ini tidak terpenuhi, maka salah satu pihak mempunyai hak untuk meminta adanya perjanjian untuk dibatalkan (voidable atau vernietigbaar), sedangkan syarat ketiga dan keempat merupakan syarat obyektif karena mengenai obyek dari perbuatan hukum yang dilakukan dan jika syarat obyektif ini tidak terpenuhi maka perjanjian batal demi hukum. Syarat keempat kausa yang halal maksudnya isi atau dasar perjanjian harus halal atau bukan kausa yang terlarang atau kausa yang palsu yaitu kausanya tidak bertentangan dengan undang-undang, ketertiban dan kesusilaan ${ }^{12}$. Kebatalan suatu perjanjian yang dibuat oleh notaris dapat dibedakan menjadi beberapa hal, di antaranya yaitu13 :

a) Dapat dibatalkan (voidable/vernietgbaar), dalam hal tidak dipenuhinya syarat subyektif, yaitu :

1) Tidak adanya kata sepakat

2) Tidak adanya kecakapan bertindak dari pihak-pihak yang membuat perjanjian.

3) Akibatnya perbuatan hukum yang dilakukan tidak memiliki akibat hukum sejak terjadinya pembatalan dan di mana pembatalan atau pengesahan perbuatan hukum tersebut tergantung pada pihak tertentu, yang menyebabkan perbuatan hukum tersebut dapat dibatalkan. Akta yang sanksinya dapat dibatalkan tetap berlaku dan mengikat selama belum ada putusan pengadilan yang telah memiliki kekuatan hukum tetap yang membatalkan akta tersebut

b) Batal demi hukum (nulland void nietig), dalam hak tidak dipenuhinya syarat obyektif, yaitu :

1) Tidak ada causa/obyek perjanjian

2) Tidak mengandung causa yang dibenarkan menurut hukum

3) Akibatnya perbuatan hukum yang dilakukan tidak memiliki akibat hukum sejak terjadinya perbuatan hukum tersebut, dalam praktik batal demi hukum didasarkan pada putusan pengadilan yang telah memiliki kekuatan hukum tetap

${ }^{11}$ Ibid., Pasal 1320.

${ }^{12}$ Ibid., Pasal 1335 dan 1337.

${ }_{13}$ Mulyoto, Perjanjian: Teknik, Cara Membuat dan Hukum Perjanjian Yang Harus Dikuasai, Cakrawala Media, Yogyakarta, 2012), hlm. 44. 
c) Batal demi hukum karena Non existent, yaitu karena disebabkan karena :

1) Tiadanya yang esensi / pokok dalam perjanjian tersebut. Contoh : jual beli tidak ada harga/pokok dalam perjanjian tersebut. Utang piutang, tidak ada penyerahan uang sebagai pinjaman dari kreditur kepada debitur.

Hakim diberikan kewenangan untuk mampu mengembangkan hukum atau melakukan penemuan hukum (rechtvinding) dan pada prinsipnya hakim dalam mengambil keputusan berdasarkan Undang-Undang. ${ }^{14}$ Hakim berkeyakinan bahwa setiap orang dianggap tahu akan undang-undang atau risiko dari suatu perbuatan hukum yang telah diperbuat atau disebut dengan asas presumtio iures deiures. ${ }^{15}$ Hakim Mahkamah Agung sebelum memutus perkara terlebih dahulu memeriksa alasan-alasan kasasi dan mengenai penilaian hasil pembuktian terlebih dahulu. Pada hakikatnya hakim wajib menggali, mengikuti dan memahami nilainilai hukum yang tertanam di dalam masyarakat. ${ }^{16}$ Hakim sebagai jabatan yang memiliki fungsi yudikatif, pada dasarnya memiliki peran untuk membuktikan keberadaan suatu fakta yang dikualifikasikan sebagai delik perdata atau pidana oleh suatu norma umum yang harus diterapkan kepada kasus tertentu. Hakim juga dapat disebut sebagai penerap dari norma hukum yang berupa peraturan perundangundangan yang kemudian diikuti dengan menerapkan sanksi demi tegaknya peraturan perundang-undangan tersebut. Lemahnya peraturan perundangundangan menimbulkan konsep penemuan hukum oleh hakim. Ada beberapa pandangan yang menyatakan bahwa penemuan hukum tidak diperkenankan hakim melakukan penemuan hukum. Gagasan terhadap penolakan ini lebih disebabkan oleh ketidakmungkinan dari apa yang disebut dengan kekosongan hukum. Pandangan ini digagas oleh positivisme Kelsen, yang menyatakan bahwa “tidak mungkin terdapat suatu kekosongan hukum dikarenakan jika tata hukum tidak mewajibkan para individu kepada suatu perbuatan tertentu, maka individu-

${ }^{14}$ Meuwissen, Tentang Pengembangan bukum, Ilmu Hukum, Teori Hukum, dan Filsafat Hukum (diterjamahkan oleh B. Arief Sidharta), Refika Aditama, Bandung, 2008, hlm. 11.

${ }^{15}$ Sudikno Mertokusumo, Op. Cit., hlm. 42.

${ }^{16}$ Undang-Undang No. 4 Tahun 2004 tentang Kekuasaan Kehakiman, Pasal 28 ayat (1) jo Pasal 16 ayat (1). 
individu tersebut adalah bebas secara hukum. sepanjang negara tidak menetapkan apa-apa maka itu merupakan kebebasan pribadinya. ${ }^{17}$

Hasil penelitian berdasarkan dari putusan Mahkamah Agung yang mengacu pada pertimbangan Putusan Pengadilan Tinggi Agama Yogyakarta telah menjawab rumusan masalah yang kedua pada penulisan tesis. Pada penelitian ini telah diketemukan bahwa pelaksanaan perjanjian yang menggunakan akad mudharabah apabila mudharib (debitur) telah menandatangani perjanjian perubahan hak tanggungan yang dilakukan dengan sadar maka tidak dapat dibatalkan yang melekat pada perjanjian pokok. Berdasarkan doktrin eksekusi jika pada hari berikutnya mudharib (debitur) mengalami gagal bayar maka secara hukum atau prosedural dapat dilaksanakan eksekusi sebagai pembayaran pengembalian pembayaran akad mudharabah yang merupakan hak dari shobibul maal (kreditur). Pada prinsipnya, dalam pembiayaan mudharabah tidak ada jaminan, namun agar mudharib tidak melakukan penyimpangan, LKS dapat meminta jaminan dari mudharib atau pihak ketiga. Jaminan ini hanya dapat dicairkan apabila mudharib terbukti melakukan pelanggaran terhadap hal-hal yang telah disepakati bersama dalam akad. ${ }^{18}$

Transaksi yang ditawarkan dalam bank syariah salah satunya yaitu akad pembiayaan mudharabah. Pembiayaan Mudharabah adalah pembiayaan yang disalurkan oleh LKS kepada pihak lain untuk suatu usaha yang produktif. Dalam pembiayaan ini LKS sebagai shahibul maal (pemilik dana) membiayai $100 \%$ kebutuhan suatu proyek (usaha), sedangkan pengusaha (nasabah) bertindak sebagai mudharib atau pengelola usaha. ${ }^{19} \mathrm{Mudharabah}$ secaraa tehnisnya merupakan akad kerjasama di bidang usaha baik antara pemilik dana dan pengelola dana untuk dibuat sebuah usaha dan dikelola baik laba dibagi atas dasar nisbah bagi hasil menurut kesepakatan baik pihak pertama maupun pihak kedua. Namun, bila terjadi kerugian maka akan ditanggung oleh si pemilik dana kecuali disebabkan oleh pengelola dana itu sendiri. ${ }^{20}$

17 Satjipto Rahardjo, Membedah Hukum Progresif, Kompas, Jakarta, 2007, hlm. 248-249.

18 Fatwa Dewan Syari'ah Nasional No. 07/DSN-MUI/IV/2000 tentang Pembiayaan Mudharabah (Qiradh), hlm. 1

${ }^{19}$ Ibid. 95.

${ }^{20}$ Muhammad Syafi'i Antonio, Bank Syariah dari Teori Ke Praktik, Gema Insani Press, Jakarta, 2001, hlm. 
Mudharabah secara teknisnya merupakan akad kerjasama di bidang usaha, baik antara pemilik dana dan pengelola dana untuk dibuat sebuah usaha dan dikelola baik laba dibagi atas dasar nisbah bagi hasil menurut kesepakatan baik pihak pertama maupun pihak kedua. Namun, bila terjadi kerugian maka akan ditanggung oleh si pemilik dana kecuali disebabkan oleh pengelola dana itu sendiri. Akad mudharabah ada dua jenis, yaitu mudharabah mutlaqah dan mudharabah muqayyadah. Pada mudharabah mutlaqah pemodal tidak mensyaratkan kepada pengelola untuk mengelola untuk melakukan jenis usaha tertentu. Jenis usaha yang akan dijalankan oleh mudharib secara mutlak diputuskan oleh mudharib yang dirasa sesuai sehingga disebut mudharabah tidak terikat atau tidak terbatas. Pada prinsipnya pelaksanaan perjanjian yang menggunakan akad mudharabah tidak diharuskan menggunakan jaminan, jaminan hanya boleh diminta apabila dimungkinkan jika debitur akan melakukan kelalaian. Jaminan yang telah diserahkan juga hanya boleh di esksekusi ketika pihak debitur telah benar-benar melakukan kelalaian. Dalam putusan Kasasi Nomor 541K/Pdt/2006 Mahkamah Agung berpendapat bahwa dalam perjanjian penjaminan harus mengacu kepada perjanjian pokok dikarenakan sifatnya yang accessoir. Di dalam perjanjian pokok kredit antara debitur dan kreditur telah menemukan bahwa yang memiliki kewenangan untuk memeriksa, mengadili dan menyelesaikan perkara a quo merupakan kewenangan hukum Negara dan pengadilan Singapura sehingga hukum Indonesia tidak mempunyai kewenangan mengadili perkara a qou. Ketentuan Undang-Undang menyimpulkan mengenai sifat accessoir yang berkaitan dengan perjanjian pokok yaitu tidak ada penanggungan tanpa adanya perutangan pokok yang sah.

\section{Daftar Pustaka}

\section{Buku}

Antonio, Muhammad Syafi'i, Bank Syariah dari Teori Ke Praktik, Jakarta: Gema Insani Press, Jakarta, 2001.

Harsono, Budi, Hukum Agraria Indonesia: Sejarah Pembentukan Undang-Undang Pokok Agraria, Isi dan Pelaksanaannya, Djambatan, Jakarta, 2008, 
Meuwissen, Tentang Pengembangan hukum, Ilmu Hukum, Teori Hukum, dan Filsafat Hukum, (diterjamahkan oleh B. Arief Sidharta), Refika Aditama, Bandung, 2008.

Mertokusumo, Sudikno, Mengenal Hukum, Universitas Atma Jaya Press, Yogyakarta, 2010.

Mulyoto, Perjanjian: Teknik, Cara Membuat dan Hukum Perjanjian Yang Harus Dikuasai, Cakrawala Media, Yogyakarta, 2012.

Rahardjo, Satjipto, Membedah Huk um Progresif, Kompas, Jakarta, 2007.

Soekanto, Soerjono \& Sri Mamudji, Penelitian Normatif Suatu Tinjauan Singkat CV Rajawali, Jakarta, 2008.

Subekti, R. \& R Tjitrosudibio, Kitab Undang-Undang Hukum Pertdata, Pradnya Paramita, Jakarta, 2008.

\section{Makalah}

Hernoko, Agus Yudha, "Hukum Perdata: Hukum Orang \& Keluarga", Bahan Kuliah Fakultas Hukum Universitas Islam Indonesia, Yogyakarta, 2017.

\section{Peraturan Perundang-Undangan}

Kitab Undang-Undang Hukum Perdata.

Undang-Undang No. 4 Tahun 1996 tentang Hak Tanggungan Atas Tanah Beserta Benda-Benda yang Berkaitan dengan Tanah.

Undang-Undang No. 4 Tahun 2004 tentang Kekuasaan Kehakiman. 